\title{
Writing Compositions from Audience Perspective: Norms and Pragma-Stylistics
}

\author{
Acheoah, John Emike ${ }^{1}$, Olaleye, Joel Iyiola, Ayankogbe, Beatrice Osaro \\ Department of European Languages, Federal University, Birnin-Kebbi, Nigeria. \\ Department of English, Waziri Umaru Federal Polytechnic, Birnin Kebbi, Kebbi State, Nigeria. \\ Department of Linguistics, African and Asian Studies, University of Lagos, Lagos, Nigeria.
}

\begin{abstract}
In every language, continuous writing (compositions) which include informal letters, formal letters, semi-formal letters, narrative essays, descriptive essays, argumentative essays, expository essays and other more technical categories of writings are audience-driven - their different parts are written in accordance with the audience which can either be formal or informal, professional or non-professional, singular or plural, young or old, specific or unspecific. Hinging on some principles within the purview of contemporary English usage, pragmatics and stylistics, this paper simply investigates the conventional and pragmatic factors which influence writings when viewed from the audience perspective. In this paper, we use an uncommon approach - the use of letters and essays to analyze issues bordering on formal and contextual properties in continuous writing. On the whole, the paper concludes that pragmatic and stylistic motivations abound in the different categories of writings.
\end{abstract}

Keywords: Audience, Composition, Pragmatics, Stylistics, Letters, Essays

\section{INTRODUCTION}

Writing involves more than making letters or other symbols on paper. Learning any language presupposes learning the four basic language skills: listening speaking, reading and writing. The present study is an attempt to examine both formal and pragmatic factors that inform writers' communicative strategies (choice of words and grammatical structures in the writing of compositions that is, different types of letters and essays).There are different variables a writer should manipulate for effective interaction, which is the core of writing. These variables include: audience, occasion and purpose. However, this paper discusses how "audience" directs writing; we examine the norms (conventions of different types of compositions) and the pragmatics (contextual or extra-linguistic factors in language use).

\subsection{The Term "Writing"}

Writing is an act (it is mechanical) and an art (it involves creativity).The process of writing involves a writer's interaction with his audience (the reader or readers). Thus, a good writer has mastery of his audience and does everything possible to put in place, those communicative strategies that make his writing convey meaning to his reader(s). The audience of a piece of writing gives it direction. In the process of writing, a writer graphically produces his ideas in a generally acceptable manner and organizes his thoughts at the same time. This is why writing is seen as the most tasking and difficult of the four language skills. Trask (1995:1) observes that language, which differentiates man from other creatures, is the tool for writing. According to Babatunde (1998), writing is a process (it is a step-by-step activity) and an interaction - it is germane to audience, occasion and purpose.

\subsection{Stages in Writing}

A process, writing involves stages (steps) which are mechanically and mentally followed to realize a good text. These stages are pre-writing, writing and post-writing stages.

\subsubsection{Pre-writing Stage}

At the pre-writing stage, activities are done before actual writing and such activities include:

$>$ choosing a topic

$>$ limiting the topic

$>$ selecting ideas

$>$ organizing ideas

${ }^{1}$ Corresponding Author: actualemike@gmail.com 


\section{American Research Journal of English and Literature, Volume 1, Issue 6, 2015 ISSN 2378-9026}

\subsubsection{Writing Stage}

This is the actual writing of texts which are mere drafts. The materials written are products of choosing a topic, limiting the topic, selecting ideas, organizing ideas, brain-storming, information gathering and jotting (all of which constitute the pre-writing stage). At the writing stage, the introduction, body and conclusion are produced (that is, the beginning, the middle and the end respectively).

Different approaches abound on how to begin an introductory paragraph. Eko (1999:25) cited in Adedimeji (2009:139) lists them thus:

$>$ Relating a Personal and Interesting Anecdote

$>$ Beginning With an Interesting Quotation

$>$ Summarizing a Commonly Held View in The Body of the Essay

$>$ Explaining The Specific Occasion That Gave Rise to the Essay

$>$ Emphasizing the Importance of the Subject Matter of the Essay

The body, otherwise called the middle, should be blown up using paragraphs that are logically and coherently linked to justify the Thesis Statement.

A composition should end well just as it is expected to begin well. However, it is the nature of the text that determines the conclusion that is appropriate for it.

\subsubsection{Post-writing Stage}

It involves activities which take place after actual writing i.e. editing and revising. This stage is very important, because writing is not a one-directional activity. There is forward and backward modifications (additions and omissions). Writing is therefore recursive.

\subsection{Crafting, Composing Coherence, Unity and Dominant Thesis}

Other important notions in writing are "Crafting", "Composing", "Coherence", "Unity" and "Dominant Thesis". These notions capture things a writer should do to ensure effective communication. Crafting has to do with structuring texts in particular patterns while composing is the expressing of ideas meaningfully. These two notions have basic requirements. For example, to compose, a writer needs to gather and organize relevant materials for the writing task. He also needs to know the contexts of writing (occasion, audience, medium and purpose). For effective crafting, a writer needs to know the various forms of writing and how to organize information properly. The Dominant Thesis is a declarative statement (sentence) that shows the attitude of the writer to the subject matter, and it serves as the anchorage of the subject matter of the composition.

Every good composition must have unity and must be coherent. By unity, it is meant that the essay discusses a main idea and that each paragraph or section of the essay contributes to the development of an aspect of that main idea. Coherence in writing means that sentences are properly linked to one another by means of appropriate linking words, and that ideas are linked across sentences in logical and sequential manner.

\subsection{Theoretical Underpinnings}

$>$ The present study makes an incisive overview on linguistics, stylistics and pragmatics, to capture the purpose of the study, which is mainly to:

$>$ Identify what constitute norms (linguistics) in the writing of different types of texts;

$>$ Locate stylistic and pragmatic choices as opposed to norms in the writing of different types of compositions; and

$>$ Explain how audience phenomenon informs linguistic, stylistic and pragmatic choices in vocabulary, layout and grammatical structures. Insights from the above three domains are highlighted in this section:

\subsubsection{Stylistics}

Defining stylistics presupposes a clear understanding of the term 'style", which refers to the way language is used in a given context, by a given person, for a given purpose. Style relates the critic's concern of aesthetic properties with the linguist's concern of linguistic description. It should be noted that creativity is often displayed by writers of non-literary works for the purpose of capturing audience and context phenomena. Style is within this field of study, 
interpreted as the selection of certain linguistic forms or features over other possible ones. Abochol (2011) cites that a court can use the expression sign: NO NOISE to stylistically convey the following messages:

$>$ The statement is a command

$>$ It is cast in an imperative mood

$>$ The statement lacks a subject and a verb

$>$ There is implied THERE SHOULD BE

$>$ The statement is unpunctuated Capitals have been used for emphasis

$>$ Simple vocabulary to suit wide audience

$>$ Extreme compression for rapid comprehension

$>$ Form entirely suited to audience and function

\subsubsection{Pragmatics}

The word "pragmatics" is from the Greek word "pragma" which means "deed" or "action". Pragmatics emerged as a reaction against the hitherto purely formalist approach to language study. This approach deprived man the opportunity to negotiate a meaning to the world instead of extracting the meaning that is already there. The emergence of pragmatics replaced "linguistic competence" (the ability to explore the linguistic conventions of writing) with "communicative competence" (e.g. exploring audience-related principles in writing). Indeed, the pragmatic analysis of language in compositions and in other types of texts can be broadly understood to be the investigation into that aspect of meaning which is derived not from the formal properties of words and constructions but from the way language is used according to contextual nuances.

\section{THE Writer's AUdiEnCE}

The writer's audience is his reader(s). Since the aim of the text is to convey the writer's message, the writer's audience is whoever the writer interacts or communicates with through writing. For a comprehensive discussion of audience phenomenon, the following terms are preferred in this paper:

\subsection{Specific and Non-specific Audience}

Compositions are sometimes meant for a specific audience (one or more than one person). It may also be meant for an unspecified audience. When a student is asked to write an article suitable for publication in a national newspaper, his audience is not specific. But when the student is to write a letter to the Editor of a newspaper, his audience becomes specific.

\subsubsection{Formal and Informal Audience}

Formal writings are directed to formal audience. It is not merely the relationship between a writer and his audience that makes the audience formal. Rather, the purpose or context of writing determines whether the audience is formal or informal. For example, a student who writes a letter to his father, requesting his tuition fee, writes an informal letter. But in a situation where this student writes a letter of application to this same father, who is the Manager of the company that the application letter is meant for, writes a formal letter, given the context and purpose of writing. Formal writings may be essays or letters. Without considering the context and purpose of writing, an informal audience is basically the audience with whom the writer has some affectionate relationship; the atmosphere is therefore lax, casual and cordial. Writing should be made as natural as possible, to capture audience phenomenon.

\subsubsection{Professional and Non-professional Audience}

A writer may have to write to his/her professional colleagues. If as a Divisional Police Officer, one writes a letter to the Inspector General of Police, to give him Situation Report (SITREP) of a crime incidence, professionalism will reflect in the linguistic structure of the text. Laboratory reports are meant for professional audience; parts of the text may not be understood by someone who is not in the profession from which the text emanates. An essay meant for the general public is not expected to be technical since it s not for professional audience.

\subsubsection{Semi-formal Audience}

If a writer intends to convey certain attitudes in writing, based on some premises, his informal audience could be treated as a semi-formal audience. An example is when a writer writes a letter to an elderly, intimate family friend, pleading that this family friend should settle the dispute in the writer's family. Another example is when one writes to an unknown pen-friend. Similarly, a student can write a semi-formal letter to his teacher, pleading for a make-up text. 


\subsubsection{Immediate and Remote Audience}

An example of a composition to an immediate audience is an essay or letter to a specific person(s). When a writer writes a letter to the Editor of a newspaper establishment (immediate audience), discussing sports hooliganism, he expects the letter to be published for readers' digest, and such readers (remote audience). This is because the writer cannot tell those that will eventually read the text. Knowledge of the readers would have given the writer the opportunity to be very exact in appropriate selection of linguistic structures.

\subsubsection{Mixed Audience}

An essay may be meant for a wide range of people: young, old, those who are aware of the subject, those who are ignorant of it, the highly placed people in society, the common man, the highly educated, those with little education, illiterates, those affected by the subject, those not affected by the subject.

\subsection{Writing for the Specific and Non-specific Audience}

When a writer knows his audience, be it a person or group of persons, the writer can decide appropriately on language choice. In a letter to a cousin or an uncle, a writer can flout rules of writing (norm) to create room for informality in tone. The writer, in doing this, may not go straight to the point in presenting the main purpose of the text because this writer demonstrates his/her awareness or mastery of writer-audience relationship. If the audience is not specified, as in the writing of articles to a mixed audience, the writer is careful not to take things for granted not to make use of "asides" and irrelevant details that would have been appropriate if it were a letter to one's uncle; see Bach and Harnish (1979) and Acheoah (2015) for insights on presupposition as a crucial concept in pragmatics. A letter may be written to an unknown adult, in which case, the audience is non-specific. Thus, language takes pragma-stylistic modifications to capture the semi-formal context of the text.

\subsection{Writing for the Formal and Informal Audience}

A composition meant for a formal audience is distinct in style (language and layout). For example, the following are the formal features of formal letters:

$>$ Address and Date;

$>$ Name, Designation and Address of Receiver;

$>$ Reference Number (as in business letters);

$>$ Greeting;

$>$ Letter Heading (in some cases);

$>$ Body;

$>$ The Subscription/Complementary Close.

The use of colloquial expressions, slang and abbreviations such as "Oct." (for "October") and "pls." (for "please") are not acceptable in formal letters because they are unsuitable for the formal audience. Similarly, salutations that are acceptable in informal letters are not acceptable in formal letters. For example, the writer of an informal letter is expected to use the form: "Dear and First Name of Receiver" as salutation in an informal letter, whereas in a formal letter, the salutation to use is: "Dear Sir" or "Dear Madam". Also, different subscriptions are used in formal and informal letters. For a formal letter, "Yours faithfully" is used while "Yours sincerely" or "Yours affectionately" is used in an informal letter. Other subscriptions that depict close relationship between writers and audience are also appropriate: "Yours ever", "Yours truly", "Your love", "Your son", (depending on who the audience is). In formal letters, the signature and full name of the writer follow the complementary close/subscription: "Yours faithfully + signature + full name of writer) whereas in informal letters, the complementary close/subscription is followed by the writer's first name only.

Within the formal audience, differences abound, and this creates room for certain conventions in language use. For example, the occupations of certain recipients are reflected in the salutations of some formal letters. The religious and legal professions are examples. Consider:

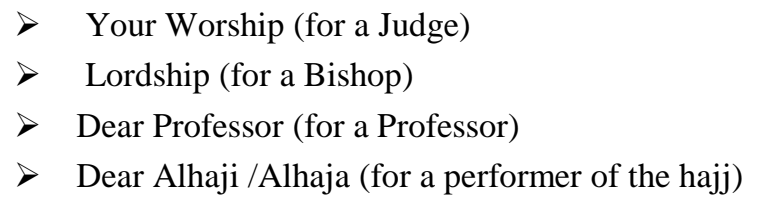




\section{American Research Journal of English and Literature, Volume 1, Issue 6, 2015 ISSN 2378-9026}

Abbreviations may be insulting in formal letters. An expression that has a positive denotation in one language may have a negative denotation in another language.

Another dimension, in which writers demonstrate mastery or consciousness of audience perspective in writing, is in the use of sentence structure. In formal letters, sentences are to be short, unlike in informal letters where sentences may be long. Also, intrusions are not used in formal letters. Intrusions are markers of informal language. They are words thrown in at different moments when writing or speaking, to make the atmosphere livelier although such words do not add to the meaning of sentences e.g.:

$>$ Look after your baby, young lady, don't be cruel;

$>$ He didn't give us the money as promised, you know;

$>$ Kemi made away with it, the rogue, but she'll smell hell.

It is necessary to note that unlike speaking, all forms of continuous writings are basically polite (have some formality), although the degree of politeness varies. Certain expressions are suitable for informal audience while others are appropriate for formal audience. Consider the following examples:

\subsection{Making Requests and Expressing Apologies}

\begin{tabular}{|l|l|}
\hline Informal Audience & Formal Audience \\
\hline 1. Send me those pens as soon as possible. & $\begin{array}{l}\text { We would be most pleased if you would send me those } \\
\text { pens as soon as possible. }\end{array}$ \\
& $\begin{array}{l}\text { Or } \\
\text { We should be very grateful if you could send me those } \\
\text { pens as soon as possible. } \\
\text { We regret my inability to attend the meeting. } \\
\text { Or } \\
\text { 2. We are truly sorry that we could not attend the } \\
\text { meeting. }\end{array}$ \\
$\begin{array}{l}\text { Or } \\
\text { We are terribly sorry for not being able to attend the } \\
\text { meeting. }\end{array}$ & $\begin{array}{l}\text { being able to attend the meeting. } \\
\text { Or }\end{array}$ \\
$\begin{array}{l}\text { We he are sincerely wished to tender an apology for not } \\
\text { attend the meeting. }\end{array}$ & being able to attend the meeting. \\
\hline
\end{tabular}

\subsection{Requesting Reply}

\begin{tabular}{|l|l|}
\hline Informal Audience & Formal Audience \\
\hline 1 Please reply as soon as you can. & It would be very appreciative if you could reply as soon as possible. \\
Or & Or \\
We'd be most glad to have your early & We should be very grateful if this letter could be favored with an \\
reply. & early reply. \\
\hline
\end{tabular}

\subsection{Writing for the Professional and Non-professional Audience}

The laboratory report (which is not one of the types of texts we shall analyze in this study), is an example of a text meant for the professional audience. A report is an account of something seen, heard or investigated. It may be written after a meeting or after a fieldwork. Laboratory reports are written after carrying out an experiment or observation. The features of the laboratory report have to be reflected in the text to serve the needs of the audience.

These features include:

$>$ The Use of Past Tense;

$>$ Writing the Title, Aim, Apparatus/Subject for Experiment, Research or Diagnosis in the Introduction (Based On the Type of Laboratory Report);

$>$ Using Diagram, Procedure/ Method, Precaution, Observation, and Readings/Calculations in the Body of the Text;

$>$ Writing the Conclusion in the Form of Final Results (Confirmation of Hypothesis or the Discovery of a New Phenomenon);

$>$ Using Specific Details; 
$>$ Being as Direct as Possible;

$>$ Objectivity;

$>$ Use of appropriate words (dictions).

When writing for the non-professional audience, style is not necessarily technical. An essay titled: "Corruption in Nigeria" is meant for mixed audience, and the context of writing is non-professional; the writer is not mindful of registers and occupationally informed style.

\subsection{Writing for the Semi-formal Audience}

The semi-formal audience has already been explained and exemplified in this study. The following are language choices suitable for the semi-formal audience when expressing an apology or requesting a reply:

\subsubsection{Expressing Apology}

$>$ We are sorry that we did not attend the meeting.

$>$ We must apologize for my inability to attend the meeting.

\subsubsection{Requesting Reply}

$>$ We should be most grateful if you reply soon.

$>$ Could you, please, let me have your reply as soon as possible?

\subsection{Writing for the Immediate and Remote Audience}

Issues discussed in this paper, on how to write for the specific audience, are applicable when writing for the immediate audience. Similarly, issues already explained, on the writing of essays for a mixed audience, are applicable when writing for the remote audience. The terms "immediate" and "remote" audience have therefore been used in this study, to state that, other people apart from the writer's main targets/audience (as obtainable in letters to Editors in newspaper columns), may read the text. However, the writer has to be skillful enough in using language. His/her language and style must be suitable for his/her first (immediate) audience. An example of a written text meant for the immediate audience, but which consequently becomes open to the remote audience, is an open letter to the President, published in newspaper. In such a context of writing, the writer, apart from controlling language to capture the style needed for his immediate audience (considering the status of the President), is equally interested in the Nigerian people who buy and read newspaper columns. But because these people are not the writer's direct or immediate audience, expressions such as: "Mr. President", "Your Excellency", etc. are to be used in the text. In a writing of this kind, language is polite, irrespective of the writer's mood.

\section{Presentation and Analysis of Data}

In this study, we shall examine some letters and essays and make relevant comments; in making such comments which are essentially analytical, some references will be made to the literature of pragmatics. Texts to be analyzed are extracted from the corpora and numbered progressively across corpora for easy referencing. In all, eighteen texts numbered (i)-(xviii) are generated. The corpora are labeled as Corpus A, Corpus B, Corpus C and Corpus D as presented below3:

\section{Corpus A}

St. Peters College,

P.M.B. 2345,

Ikoyi, Lagos.

December $10^{\text {th }}$,

2012

Dear Augustine,

Your letter was received in good time. How your family dey na?

It is necessary to let you know exactly how it happened. The young man is a dealer, and because I have not been mobile for long, it became very necessary to be close to him. I may get one and make installmental payment. He isn't the type who imports V-Boots. In fact, customers who need state- of- the- art cars get very close to him.

Anyway, when we see sha, I will tell you the type of Macleans that you will need for a fresher breath, as you requested in your last letter.

Your guy, Tope. 


\section{Corpus B:}

\section{Survival of the Fittest}

At times, I wonder why life is full of struggles that do not seem to end. Man is born free but endless struggles do not depict the slightest of freedom; without having to go through a toilsome experience, man is denied the freedom to get shelter clothing and food. This is the status-quo in my country, where the young and the old struggle for survival; but as the going gets tough, only the toughs get going or better still, only the fittest survive!

The situation in Nigeria has reached crisis point as university graduates now do various "things" to earn a living: trading, armed robbery, 419, comedy, and so on. Whatsoever they take up as their basis for survival, is informed by the need to survive. Only a few decide to take up reasonable or legitimate ventures to earn a living. A good example is a friend, Mr. Ada, who, converting the unemployment situation in the country into a blessing, set up a business center in a university campus, although his photocopy machines were unreliable. As a way of making more profits to be able to pay his bills, he also sold pure water and Ragolis.

To cut the story short, Mr. Ade thrived in his trade. This is survival of the fittest!

\section{Corpus C:}

No 45,

Okumagba Layout,

Benin City,

Edo State.

$12^{\text {th }}$ December, 2009.

The Principal,

Idia College,

P. M.B.321,

Benin City,

Edo State.

Dear Sir,

\section{STUDENTS' MISCONDUCTS}

The attitude of students in the junior classes in particular, has not been good. I have made several efforts to check their misconducts, but all to no avail. This has necessitated this letter.

Sir, the students, particularly those in the junior classes, are fond of behaving as if they do not Know the school's rules and regulations. They go to buy food in nearby restaurants amidst lecture hours. In fact, those of them who come to school with sufficient money do not buy food from mama-put. Rather, they buy from restaurants. This does not give our school a good image.

Sir, I shall be glad if you intervene in this ugly situation so that Idia College can be what it used to be; a place where future leaders are trained!

Yours faithfully,

Ads 
American Research Journal of English and Literature, Volume 1, Issue 6, 2015

ISSN 2378-9026

Udo Udoji

Corpus D:

\section{A BLESSING IN DISGUISE}

Ada's experience really makes clear, the popular saying that 'every disappointment is a blessing'. She was a lady striking in age, and was therefore very anxious to know the will of God.

One Tuesday morning, Ada was on her way to the market when a young man suddenly called her name. She wondered who knew her name at that part of the town. But as she tried to look at the direction from where the voice came, she discovered it was her school mate at the university. The young man, about forty years of age, was also waiting, although not as anxiously as Ada.To cut the story short, Uzoma asked Ada's hand in marriage. Gladly, Ada accepted. Their courtship was longer than expected, so Ada became worried. She felt she was not charming, and resorted to improving her looks. Every month, she visited the cosmetic stores for Vaseline "gongon" so that her skin would have the needed greasy look. This was her routine when ten months later, Uzoma suddenly wrote to tell Ada: "We are no longer your taste because 'levels don change' ".Ada wept bitterly and after a few months, she relocated to the village, where as God would have it, she met another suitor who got married to her in a matter of weeks. What a blessing in disguise!

The following items will be examined in Corpus A:

(i) St. Peter's College,

P. M. B.2345,

Ikoyi, Lagos.

December $10^{\text {th }}, 2012$.

(ii) Dear Augustine,

(iii) How your family dey na?

(iv) dealer

(v) he isn't

(vi) V-Boots

(vii) Anyway, when we see sha

(viii) Macleans

(ix) Your guy,

Tope.

In Corpus B, texts selected for analysis include:

(x) 419

(xi) business center

(xii) Pure water and Ragolis

Corpus $\mathrm{C}$ has the following texts to be analyzed:

(xiii)

No 45,

Okumagbe Layout,

Benin City,

Edo State.

$12^{\text {th }}$ December, 2012.

The Principal,

Idia College, P. M. B. 321,

Benin City, 
American Research Journal of English and Literature, Volume 1, Issue 6, 2015

ISSN 2378-9026

Edo State.

Dear Sir,

\section{STUDENTS' MISCONDUCTS}

(xiv) mama-put

(xv) Yours faithfully, Ads

Udo Udoji;

(xvi) the will of God;

(xvii) Vaseline "gon-gon";

(xviii) 'levels don change'.

\subsection{The Analysis}

The writer of Corpus A uses the convention of writing in his choice of (i); when the audience is informal, only one address is used.

In (ii), the norms of writing informed the writer's choice of the salutation: Dear + First Name of Receiver. However, first name of the receiver is not applicable in certain informal contexts, for example, if the receiver is one's father or mother; in this case, the writer will use the salutation: "Dear Father" or "Dear Mother". If the audience were formal, the writer is expected to use the form: "Sir" or "Dear Sir". Some scholars are of the opinion that "Sir" is more formal than "Dear Sir".

Text (iii) is Pidgin English. The writer is aware that his audience can decide what the utterance means. As Bach and Harnish (ibid.) puts it in their theoretical frame, when S (Speaker) utters an expression, e, in a given Linguistic Community, LC, to $\mathbf{H}$, (Hearer), it is expected that the hearer will understand or identify what the speaker means by the expression. This is because the speaker utters it with some known illocutionary intent. Linguistic Presumption, $\mathbf{L P}$, refers to the moral belief that members of a linguistic community share on a particular language, $\mathbf{L}$.

In (iv), "dealer" has not been used denotatively, but contextually. The native speaker of English will not understand the meaning of this expression in Corpus A. However, the decoder of this text does not strife with the meaning of the utterance since there is writer-reader shared knowledge (what Bach and Harnish (ibid.) calls Mutual Contextual Beliefs). Unlike the writer's audience who understands what the expression "dealer" means in the letter, a reader who is bereaved of the socio-pragmatic and diachronic contexts of the text, will rely on the synchronic context, that is, the text per se, to decode meaning up to an extent. The synchronic context speaks to alienated reader through the agency of the words before and after the word "dealer" in the letter.

The contracted form of the verbal element "is not", which is "isn't", as used in (v), is preferred by the writer of the letter due to the provisions of the norms of writing; language is made to reflect audience phenomenon in the writing. The expression "isn't" (contracted verb) is informal, in the same way as colloquial expressions are informal and inappropriate for formal audience. Full forms of the verb are expected in formal letters; contracted forms are impolite. This is a matter of norms - it is part of the general standard in the writing of compositions. Abbreviations (which contracted verbs also appear to be) are generally not acceptable in writings meant for formal audience.

The expression "V-Boots" in (vi) is what Acheoah (2011:121) calls Geoimlicature. Since several other vehicles have v-shape boots, one wonders why the encoder of "V-Boots" in text (vi) expects his decoder (reader) to situate the meaning of the expression; here, the writer of (vi) employs the pragmatics, not the norms, of composition writing. There are so many regional names for vehicles in contemporary Nigerian context; names which may not even be known to the manufacturers or assemblers of such vehicles. In fact, such names did not exist in Nigeria some years back. Thus, social phenomena generate lexical items, whether such lexical items are regional or cross-cultural. Below are some regional names for different kinds of vehicles in Nigeria; names which a Nigerian writer can use to communicate with a member of his linguistic community, without communication breakdown:

$>$ Honda Allah;

$>$ Honda Bullet;

$>$ Honda Pure Water;

$>$ Baby Boy (this shows that some of such names do not reflect the factory brand name); 


\title{
American Research Journal of English and Literature, Volume 1, Issue 6, 2015 ISSN 2378-9026
}

\author{
$>$ Best Lady; \\ $>$ Honda Bulldog.
}

In (vii), the writer uses an informal expression due to his awareness of his audience. The norms of writing allow this, within the context of audience. It is the use of "sha" in the letter, that captures the informality in the utterance.

The expression "Macleans" is used with a region-based meaning as evident in (viii). The writer of the text implies that the term "Macleans" is a hyponym for "Close-up", "Aqua-fresh", "Dabur", etc. which are various brands of toothpastes. However, it is wrong in terms of the "norms", to state that all brands of toothpaste are Macleans.

The writer's choice of (ix) is informed by conventionality. If the subscript were to be for a formal audience, the writer would have used what is used by the writer of Corpus $\mathrm{C}$.

The expression 419 in ( $\mathrm{x}$ ) of Corpus $\mathrm{B}$, is an example of Geoimplicature. The term, as used in Acheoah (ibid.) is derived from "geographical" and "implicature", to refer to practices that have geographical restriction in terms of people, and not just in terms of physical boundaries. Such practices (paralinguistic and linguistics components) are not globally conventional. For example, the foreign companies who assemble or manufacture certain vehicles do not have to know that such vehicles have had their factory names changed in Nigeria. Even within Nigeria, a particular vehicle has different nick-names across the states of the Federation. Pragmatics is relevant in various disciplines, with a stake on how utterances are understood. There are various commodities that could be sold in business centers. But it is observed that the Nigerian speaker is fond of using the expression "business center" to mean a place where computer operations such as photocopy services, typing, binding of written materials etc. are commercialized; the writer of text (xi) therefore has mastery of the audience and context of the composition in the selection of expressions.

"Pure water and Ragolis" as used in (xii) implies that pure water is different from Ragolis, which is actually pure water in the speech community from which the text is taken. The notion of implicature is explained in pragmatics, by H. P. Grice (1975) who, in his theory, asserts that implicatures (meanings implied in utterances) can be conventional or conversational. Conventional implicatures are generated from the conventional meanings of words used in discourse; they are lexeme-dependent. Conversational implicatures on the other hand, are generated when the Cooperative Principles (the principles of conversation established in Grice's work, Logic and Conversation) are violated. Therefore, the conventional meaning of the word "pure" takes us into various layers of meaning of the utterance $^{1}$ :

What is referred to as "pure water" is purer than what is referred to as "Ragolis";

$>$ Ragolis is actually pure, while pure water is not;

$>\quad$ Not all brands of pure water are pure;

$>$ All brands of Ragolis are pure;

$>$ Pure water is fake Ragolis;

$>$ Ragolis is original Ragolis.

The above layers of meaning have helped the writer of the text to frame the expression "pure water" as he communicates with his reader. Scholars are of the opinion that tautologies can be used informatively; it is therefore plausible to state that in the use of the regional choice of words, writers are mindful of both the norms and the pragmatics of writing, which is the thrust of this paper. We do not attempt to lampoon deviations from the norms of English as evident in regional usages, but to explain such deviations as elements of cross-cultural pragmatics.

Following the formal features of an official letter, the writer of text (xiii) ensures that the letter takes two addresses (that of the writer on the right, and that of the receiver on the left) side of the page. Also, just as the writer has done, official/formal letters take titles which are framed according to the topic.

The expression, "mama-put" (a compound noun), is used because in the linguistic community where the text is generated, the expression means "a less standard place for buying and/or eating food; such a place is viewed as being less than the standard of a restaurant, despite the fact that it might be a room, just as a room can be used as a restaurant. However, some "mama-put" joints are mere shades for outdoor meals. We postulate that the reasons why such joints are nick named "mama-put" are as follows":

$>$ They sell very cheap food;

$>$ The sellers/ are not educated or sophisticated; 


\section{American Research Journal of English and Literature, Volume 1, Issue 6, 2015 ISSN 2378-9026}

$>$ The food sold there is not delicious;

$>$ The food sold there are not in varieties;

$>$ The food they sell is not prepared in hygienic ways;

$>$ The places are not attravtive;

$>$ The customers are either poor/uneducated/unsophisticated adults or children of the poor;

$>$ The utensils or cutlery are unsophisticated;

$>\quad$ The method of selling is crude.

Text (xv) is informed by the conventional layout for formal letters. In informal letters, the use of the full name of the writer is unacceptable. Similarly, the writer is not expected to sign.

It is common to find Christians in Nigeria, irrespective of their denominations, using the expression "knowing the will of God" to mean "knowing God's wish in marriage as used in (xvi) of Corpus D. If a speaker tells his hearer, "we am old enough to know the will of God", and without adding "...in marriage" to the latter, the hearer decodes the meaning of the utterance, it is because S (Speaker) and H (Hearer) share common ground knowledge of the meaning of the locutionary act (see Austin's 1962 classification of speech acts into locutionary, illocutionary and perlocutionary acts) after all, the "will of God" is not restricted to marriage, but covers everything that pleases God, marriage inclusive.

In (xvii), Vaseline "gon-gon" implies that several other pomades are not the brand called Vaseline by the manufacturers, but by the people in the linguistic community who have reasons for the generic use of the term. In the sense that the writer of Corpus D has used the expression, it can be concluded that he shares common ground knowledge with his reader, that e (the expression as in Bach and Harnish's Theory), means that any pomade irrespective of the brand, is Vaseline. Thus, the term Vaseline is regarded as a super-ordinate term for any thick, greasy substance used for rubbing and soothing the skin.

The way the writer of (xviii) uses the utterance (Pidgin English), shows that the relationship between a writer and his audience is often reflected in writing. Essentially, this makes writing natural both in formal and informal contexts.

\section{CONCLUSION}

Writing is not just an act (a mechanical process), but it is also an art (creativity is infused into the mechanical process of writing). Every good writer/writing is directed by audience, purpose, topic and occasion: these variables have to be consciously and skillfully manipulated towards effective to writing. Stylistic and pragmatic competences inform good writing of various types of texts: letters as well as essays and their typologies. The stylistic factors have to do with knowing the norms or conventions not just of the linguistic code of the text, but also knowing the suitable style or what constitutes the layout (formal features).The pragmatic factors on the other hand, pertains to communicative competence rather than linguistic competence (what Ferdinand de Saussure calls "parole" and "langue" respectively). Howbeit, a writer relies on first-hand linguistic ability to deviate from norms to pragmastylistic choices. But such deviations are effectively communicative because they are driven by the writer's mastery of his audience, topic purpose and occasion. Of these variables, audience is super-ordinate in the sense that it informs the others in one way or the other. For example, the type of audience that a written speech is meant for, determines the topic a writer chooses; in this regard, a speech meant for a gathering of secondary school youths may be titled: "Dangers of Juvenile Deliquency" or "Avoiding Pre-marital Sex" and not "Dangers of Divorce". Although many writers find effective writing cumbersome, it is attainable even with appreciable ease, if only some conventional rules (norms) and principles (pragmatic and stylistic forces) of writing are explored.

\section{Activity}

The following activities are useful:

Divide the class into short groups of six students. Make each group read speeches delivered to different audience. Consider these:

$>$ A speech delivered by the President of the Young Farmers' Club of a school, to the members;

$>$ A speech delivered by the Chairman at a Send-forth Ceremony, to the guests;

$>$ A speech delivered at a Naming ceremony of a child; 


\section{American Research Journal of English and Literature, Volume 1, Issue 6, 2015}

ISSN 2378-9026

$>$ A speech delivered by the Principal of a college at an Annual Briefing;

$>$ A speech presented by the Head-boy of a college, on the occasion of the school's Annual Speech and Prizegiving Ceremony.

\section{Notes}

$>$ See Adegbija (1982) for tips on the "pragmasociolinguistic" concept which captures layers of meaning in the decoding of utterances.

$>$ It should be stated that some of the above submissions can be refuted; for example, there are some sophisticated canteens that do not sell delicious food.

$>$ Errors of punctuation, grammar and expression in the corpora are presented as made by the writers.

\section{REFERENCES}

[1] Abochol, S. I. (2011). Language and Society: An Introduction. Abuja: Chartered Graphic Press.

[2] Acheoah, J. E. (2011). “A Pragmatic Analysis of Ayi Kwei Armah’s The Beautyful Ones Are Not

[3] Yet Born." Zaria: Department of English and Literary Studies, Ahmadu Bello University. Unpublished Ph. D Dissertation.

[4] Adedimeji, M. A. (2009)."Basic Principles of Effective Writing. " In Alabi, V. A. "The Use of

[5] English in Higher Education. Ilorin: The General Studies Division, University of Ilorin,

[6] pp. $135-154$.

[7] Adegbija, E. (1982). “A Speech Act Analysis of Consumer Advertisements”. Bloomington:

[8] Indiana University. Unpublished Ph.D Dissertation.

[9] Allan, K. (1986). Linguistic Meaning Vols.I and II. London: Routledge and Kegan Paul.

[10] Austin, J. L. (1962). How to Do Things With Words. Cambridge: Harvard University Press.

[11] Babatunde, S. T. (1998). "Developing Effective Writing Skills: Basic Requirements." In Adegbija, E. E. (Ed.) Effective Communication in Higher Education: The Use of English. Ilorin:

[12] The General Studies Division, University of Ilorin, pp.185-196.

[13] Bach, K. and Harnish, R. (1979). Linguistic Communication and Speech Acts. Cambridge,

[14] Massachusetts: The MIT Press.

[15] Eko, (1999). Effective Writing. (Revised Edition). Ibadan: Heinemann Educational Books (Nig.).

[16] Saussure, Ferdinand de (1974). Course in General Linguistics. Glasgow: Fontana.

[17] Searle, J. (1969). Speech Acts: An Essay in the Philosophy of Language. New York: Cambridge

[18] University Press.

[19] Trask, R. L. (1995). Language: The Basics. London and New York:Rouledge. 